\title{
Responsibility for Acts of the President of the Czech Republic
}

\author{
BY JAN KUDRNA*
}

\begin{abstract}
This article deals with the issue of responsibility for the actions of the President. The author distinguishes among three basic forms of responsibility of the Head of State - constitutional, constitutional political and criminal responsibility. In the aggregate, they form the complex responsibility of the President. Individual types of responsibility of the President are described in the article in terms of their theoretical basis as well as mutual relations. Their origin and development within individual Czechoslovak and Czech constitutional regulations are also described. The article analyses their constitutional regulation in the Constitution of the Czech Republic until 7 March 2013, and particularly after this date when the full Constitutional Act No. 71/2013 Coll. came into effect. The Act significantly influenced the responsibility for the actions of the President. In conclusion, the author duly focuses on evaluation of the current constitutional regulation, including considerations about possible de lege ferenda improvements.
\end{abstract}

Keywords: responsibility of president, constitutional responsibility, criminal responsibility, political responsibility, Czech constitution

\section{INTRODUCTION}

The topic of responsibility for actions of the Head of State is a complicated one. Primarily, because it is this area of the law that involves a labyrinth of various forms of responsibility, which are interconnected. This issue is a topic of discussion in the Czech Republic, however, its present legal form has not been comprehensively analysed. ${ }^{1}$ The last amendment of the Constitution of the Czech Republic (hereinafter referred to as the "Constitution" and "CR") was not only limited to a change in the method of the election of the President of the Republic (hereinafter referred to as the "President") but also affected, significantly, several aspects of their position in terms of the responsibility for performance of their duties. As will be demonstrated hereafter, this constitutional amendment brought the responsibility of the acts of the President back to the original starting point.

${ }^{1}$ An exception in recent Czech professional literature is represented in an article by Prof. Jan Filip from 2010. It will form a methodical basis of our approach to this problem hereinbelow. See Jan Filip, 'K ústavní odpovědnosti v ČR a odpovědnosti hlavy státu zejména za velezradu' (2010) 1 C̆asopis pro právní vědu a praxi 21-39. Or the respective passage by the same author in: Lenka Bahýl'ová et al., Ústava České republiky. Komentár (Linde 2010) 793-825.

\footnotetext{
*The author is a lecturer at the Department of Constitutional Law, Faculty of Law, Charles University in Prague, and a member of the Department of Legal Specialisations and Public Administration of Metropolitan University Prague and can be contacted via email kudrnaj@prf.cuni.cz. The article is published within the PRVOUK 04 Programme.
} 


\section{DIFFERENT FORMS OF RESPONSIBILITY OF THE PRESIDENT OF THE REPUBLIC}

In addition to the openness of public offices to all citizens and tenure of those offices for a limited period of time, basic features defining the system of government in a republic include accountability for performance of the officeholder's duties. Yet the responsibility for performance of the officeholder's duties is not a monolithic institute. On the contrary, it is a multi-layer complex of various forms of responsibility.

In his above-mentioned article, ${ }^{2}$ which is in many respects a necessary starting point for the description of this topic in Czech professional literature, Jan Filip ${ }^{3}$ distinguishes several forms of responsibility to be considered in respect of the President, or constitutional law in general.

It is primarily the constitutional responsibility. Besides this, other forms of legal responsibility can be considered, particularly criminal responsibility. ${ }^{4}$ Professor Filip distinguishes between them and the constitutional political responsibility. A special - and in principle non-legal - type of responsibility is the political one. To a certain extent, it may but does not need to be connected with moral responsibility.

The differentiation among the constitutional, constitutional political and political responsibility as presented in Professor Filip's article is, in my opinion, particularly crucial and clarifies the complexity of the different forms of responsibility of the President to such extent that I will apply it as the basis of this article.

\section{Constitutional responsibility}

As stated by Professor Filip, the existence of constitutional responsibility is based on the recognition of the existence of constitutional torts. These are actions of subjects of constitutional law which are in conflict with the rules of constitutional law and which are directed against values protected by constitutional law. ${ }^{5}$ In the Czech constitutional system, an example of constitutional responsibility is the responsibility of the President for high treason.

Constitutional responsibility requires special legal regulations. A prerequisite is regulation by constitutional law and its rules. This form of responsibility also concerns a special subject defined by constitutional law. Actions must be aimed against values protected by constitutional law. Also, the nature of sanctions corresponds to constitutional law.

Hence, constitutional responsibility is a specific type of legal responsibility and in many respects, it has a privileged character. It does not need to rule out other forms of responsibility of the subject concerned, on the contrary, it may supplement those forms.

2 Filip 21-39.

3 A professor at the Department of Constitutional Law and Political Science, Faculty of Law, Masaryk University in Brno, and currently a judge of the Constitutional Court of the CR.

${ }_{4}$ Other forms of legal responsibility can also be considered, such as liability for offences and other administrative torts, civil liability, etc. With regard to the extensiveness of the problem and the limited scope of this text, we will not focus on all forms of legal responsibility.

5 Filip 24. 


\section{Constitutional political responsibility}

Constitutional political responsibility occurs where the confidence in a relationship established by appointment or election is violated. ${ }^{6}$ Committing a tort, as required in the case of constitutional responsibility, is not necessary. This type of responsibility takes place in the case of violation of a political programme or assignment. The Constitution does not need to be violated. The responsibility can be borne both by an individual and by a group. ${ }^{7}$

In contrast to constitutional responsibility, there is no giving of evidence or investigation. The subsequent proving of guilt is carried out in this case when drawing consequences. The withdrawal of confidence and subsequent removal are preceded only by (political) discussion.

Constitutional political responsibility is enforced by removal from office. Although the two forms of responsibility mentioned thus far can supplement each other, ${ }^{8}$ it is not the case when the President of the CR is concerned. The President cannot be removed from their office for political reasons.

Therefore, the provisions of Article 54(3) of the Constitution stipulating that the President of the Republic is not responsible for the performance of their duties must be applied to this form of responsibility.

\section{Criminal responsibility}

Criminal responsibility ranks among typical instruments of law. It is a case of drawing consequences from the infringement of values protected by criminal law. In relation to other forms of legal responsibility, it occurs in modern systems of law as ultima ratio. In this case, particularly a subject, subjective side, object and objective side of a tort must exist. Criminal responsibility is strictly individual, but there may be various forms of participation.

The application of this type of responsibility does not necessarily exclude application of other potential forms of responsibility of the President, especially constitutional responsibility. In this respect, the amendment of the Constitution of the CR was the most significant change. While until 7 March 2013 concurrence of constitutional responsibility and criminal responsibility was excluded as the President was equipped with a very extensive criminal immunity of substantive nature, after this date the concurrence of both types of responsibility has been possible. This change also affects Article 54(3) of the Constitution as it slightly narrows its meaning.

\section{Political and moral responsibility}

In addition to the clear legal types of responsibility (the constitutional and criminal responsibility mentioned herein) or the responsibility established and regulated by law but still having a political nature (the constitutional political responsibility), non-legal types of responsibility clearly exist. In the field defined by constitutional law this is primarily the political responsibility, or the moral responsibility as the case may be.

6 ibid 24 and 27.

7 This is the case of the government of the CR; on the contrary, the individual constitutional political responsibility of an individual member of the government is impossible in the CR. For example, in Poland, this form of responsibility does exist in relation to the government both in the joint and individual form.

${ }^{8}$ As is the case e.g. in the neighbouring Austria or Slovakia. 
As mentioned by Professor Filip, even though constitutional law does allow for them, they defy the principles of the rule of law as they do not necessarily rely, e.g., on presumption of innocence, proof of guilt, etc. ${ }^{9}$ The proving of guilt is not necessary but, despite this, a mere expression of suspicion or accusation is not enough. Political responsibility is a basic part of the rules of conduct, due to which the political system can function.

Moral responsibility may occur in the event of a breach of required rules of society, not necessarily in direct connection with the performance of the political officeholder's duties. It may be a violation of those rules in the private life of the politician concerned.

Political responsibility to voters or colleagues is enforced in the form of resignation from one's office; likewise in the case of moral responsibility. Voluntary resignation may often only be relative, because staying in office despite the pressure of public opinion can result in holding the office, but at the same time in the political disabling of its holder. ${ }^{10}$

Both these types of non-legal responsibility also relate to the President. Due to their non-legal nature, their application obviously cannot exclude a legal rule. ${ }^{11}$ Therefore, I will deal with them below with regard to the obvious possibility of their application.

\section{OUTLINE OF THE HISTORICAL DEVELOPMENT OF RESPONSIBILITY OF THE PRESIDENT OF THE REPUBLIC IN CZECHOSLOVAKIA}

\section{Interim Constitution}

The first constitutional document in the independent Czechoslovak Republic which made provisions for an individual Head of State was the Interim Constitution, i.e. Act No. 37/1918 Coll. of Laws and Decrees. This regulation was of considerably provisional character, which was also obvious from the merely general character of the regulation concerning the position of the President and their responsibility for performance of their duties.

It is not clear from the Interim Constitution that the President had any constitutional responsibility. No provisions were made for the possible sanctions of a constitutional tort.

On the contrary, as can be seen from the last sentence of $\S 10$ of the Interim Constitution, the President did not bear constitutional political responsibility. Each governmental act of the President had to be countersigned by the respective responsible

9 Filip 27.

${ }^{10}$ As an example of such political disabling, we can refer to the case of the former US senator Edward M. Kennedy, as mentioned, e.g., by the Polish publicist M. Ziomecki. When he was a young senator, Kennedy caused a traffic accident in which a woman travelling with him died. He did not try to save her and failed to summon assistance, on the contrary, he left the scene of the accident. For this crime he was given a suspended prison sentence. As he was a talented and popular politician, he was repeatedly re-elected to the Senate of the US Congress until his death, for seven six-year terms of office in total. Nevertheless, whenever he tried to test the potential options to gain his party's nomination as a presidential candidate, people dressed in wetsuits appeared at his meetings and receptions and thus every attempt ended there. It was therefore tolerable for a person who had failed in a fraught life situation to participate in the work of the Senate, but it was unacceptable to entrust him with the individual responsibility for managing the country. For details on the issue of political and moral responsibility, see: Mariusz Ziomecki, 'Obciach i szacun' (2013) 18 Przekrój (3536) 15.

${ }^{11}$ If we disregard the highly improbable possibility to rule out possible abdication of the President of the Republic. 
member of the government. By this countersignature the constitutional political responsibility was passed from the President to the government. Confidence in the government, not in an individual minister, could be withdrawn if need be.

From among the other legal forms of responsibility, only the Interim Constitution provides for criminal responsibility. Within its $\S 9$, it rules out criminal prosecution of the President for the term of their office.

It is evident that a concept of excluded constitutional political and criminal responsibility of the Head of State had started taking shape from the very beginning of the Czechoslovak constitutional development.

\section{Constitutional Charter}

The concept of responsibility for the performance of duties of the President in the 1920 Constitutional Charter ${ }^{12}$ is based on the Interim Constitution. To start with it does not establish the constitutional responsibility of the Head of State. Thus it does not make provisions for an option to prosecute the President for a constitutional tort, or to possibly remove them.

The President did not bear constitutional political responsibility. Within its $\S 66$, the Constitutional Charter stipulates that the government is responsible for all statements of the President related to their office, and in $\S 68$ it outlines the mandatory countersignature of each President's act of governmental and executive powers by a responsible member of the government.

The Constitutional Charter makes exclusive provisions for the criminal responsibility of the President of the Czech Republic in the case of high treason. Proceedings were to be held before the Senate upon the motion of the Chamber of Deputies. For details, the Constitutional Charter referred to another special law implementing it.

As evident from the above, we encounter a mixed solution of distinguishing between the constitutional and criminal responsibility of the President as used herein. The Constitutional Charter talks about criminal liability but uses the term high treason, which is today connected with constitutional political responsibility in the Czech Republic. Also, the proceedings where the plaintiff is one chamber of the Parliament and the judicial authority is the other chamber rather corresponds to impeachment.

In fact, $\S 67$ of the Constitutional Charter provides for the issue of criminal responsibility of the President; it only makes provisions for privilegium fori, i.e. a special body authorised to file impeachment charges and conduct judicial proceedings relating to a tort of the President.

This is demonstrated by the fact that the respective implementing law, only adopted on 21 February 1934 and published as the Act on Criminal Prosecution of the President and Members of the Government under No. 36/1934 Coll. of Laws and Decrees, does not address high treason at all. The facts of high treason were actually established in $\S 58$ of Criminal Law No. 117/1852 of the Code of the Empire. Thus, in $\S 67$ the Constitutional Charter refers to the Criminal Code and the tort provided for therein.

Eventually, the Constitutional Charter was in fact indirectly amended by Act No. 50/1923 Coll. of Laws and Decrees, for the Protection of the Republic, which expressly cancelled the above-mentioned $\S 58$ of the Criminal Code and replaced it with the provisions

12 Published under No. 121/1920 Coll. of Laws and Decrees. Available online in English at: http://archive.org/stream/cu31924014118222\#page/n1/mode/2up [cit. 05/02/2015]. 
of its $\S 1-3$. They replaced high treason with crimes in aggregate called "plots against the republic" and comprising plots, preparation for plots and threats to the republic.

This means that they were crimes equal to some of today's crimes against the republic as contained in the Criminal Code. At the time of the $1^{\text {st }}$ Czechoslovak Republic, high treason had a different meaning than today. It is also important that the Constitutional Charter did not know the constitutional responsibility of the Head of State.

\section{Ninth-of-May Constitution}

As concerns responsibility for acts of the President, the Ninth-of-May Constitution approved Constitutional Act No. 150/1948 Coll. adopting the substantial features of the previous constitutional regulations. It also did not know the constitutional responsibility of the President. In respect of the constitutional political responsibility, it fully assumed the solution adopted by the 1920 Constitutional Charter as it proclaimed the President was not responsible for performance of their duties and shifted all responsibility to the government by means of countersignature.

Regulation of the President's criminal responsibility underwent a certain change. Again, the Ninth-of-May Constitution only permitted criminal prosecution of the President for high treason. However, notwithstanding the previous constitutional regulations, it stipulated that the punishment could only be a loss of office and the eligibility to regain it. ${ }^{13}$

At this moment, elements of the constitutional and criminal responsibility of the President overlapped in the Czechoslovak constitutional development. While the President could be indicted for committing specific yet criminal acts, the punishment could only be a sanction of considerably constitutional nature. Here, we can see a real shift that will lead us to the present situation, where high treason is embodied as a constitutional tort and all of its aspects are separated from the possible criminal responsibility of the President.

The Ninth-of-May Constitution referred to a law again in detail. Until 6 October 1948 this was Act No. 50/1923 Coll. of Laws and Decrees, for the Protection of the Republic. On the mentioned date, it was replaced with Act No. 231/1948 Coll., for the Protection of the Democratic People's Republic. Act No. 36/1934 Coll. of Laws and Decrees, on Criminal Prosecution of the President and Members of the Government was nullified by the Constitution itself. Due to these changes, there was no definition of the body of high treason after 6 October 1948. It is quite another thing that in the given historical situation it was no longer a current matter.

\section{Constitution}

In respect of responsibility for acts of the President, the new Constitution passed on 11 July 1960 and published as Constitutional Act No. 100/1960 Coll. meant, a breakthrough as it formally adopted a brand new approach to these issues; despite this apparent breakthrough it did not in fact change anything.

Its key provision is Article 61(2) stipulating that the President is responsible for the performance of their duties to the National Assembly. This meant abandoning the principle

13 In reaction to the cancellation of the Senate and introduction of a single-chamber National Assembly, the Ninth-of-May Constitution also changed the procedure of high-treason proceedings, as it stipulated that the impeachment charges were to be filed by the presidium of the National Assembly and trial was to be held by the National Assembly. 
applied since 1918 in Czechoslovakia, according to which the Head of State has no responsibility.

Nevertheless, the said provision is as concise as it is inapplicable. Neither in the provision, nor anywhere else does the Constitution stipulate the consequences of the responsibility and the procedure of enforcement of responsibility.

In general terms, the said formulation is the basis for potential constitutional as well as constitutional political responsibility. The government did not assume responsibility for the exercise of presidential powers.

The issue of criminal responsibility of the Head of State is clearer. The 1960 Constitution did not bestow the President with immunity. They were formally fully criminally liable for their actions, throughout the duration of their term in office. Even in this case, the criminal responsibility also covers those actions which are, e.g., currently classified under special constitutional responsibility.

\section{Constitutional Act No. 143/1968 Coll.}

In terms of highly formal proclamation the 1960 Constitution was a mere episode in the Czechoslovak constitutional development. Eight years later, it was totally amended by the Constitutional Law of the Czechoslovak Federation published under No. 143/1968 Coll. The position of the President and responsibility for their actions was also changed.

The construction of the President's responsibility for exercising their duties to the Federal Assembly was maintained. The provision of Article 60(2) of the said constitutional act remains as short as in the amended Constitution, and there are still no implementing regulations. The question of how the responsibility would be enforced remains unanswered at the normative level. Twenty years later we can only theoretically conclude that the President could probably be removed from their office by the Parliament. Nevertheless, some authors caution that no such procedure is embodied. ${ }^{14}$

The described constitutional act opens the door to both the constitutional and constitutional political responsibility of the President for their actions. Moreover, it also suggests the regulation of criminal immunity of the President defines their criminal responsibility.

Under Article 65 of the Constitutional Act on Czechoslovak Federation, the President cannot be prosecuted for actions related to the performance of their duties. Two conclusions can be drawn from that formulation. First, formally speaking, the President could be prosecuted even during the term of their office for all crimes of a "non-official" nature. Second, the said provision meant that crimes of an "official" nature were subject to responsibility towards the Federal Assembly. In other words, the President's responsibility to the Parliament also contained the element of constitutional responsibility.

The said constitutional situation continued until the Czechoslovak Constitution ceased to exist and the Constitution of the independent Czech Republic was adopted.

\section{Responsibility for acts of the President of the Czech Republic until 7 March 2013}

In respect of the regulation of responsibility for acts of the President, the Constitution prepared for the independent Czech Republic was influenced by several factors.

First, it was prepared under the premise that it was to be the real fundamental law of the state. It no longer had to be a façade legal rule of a more or less declaratory nature,

14 Stanislav Zdobinský et al., Československé státní právo (Prague 1988) 148-149. 
because the political operation is managed without the aid of the Constitution. On the contrary, in the environment of plural democracy where no single political centre of power exists, political conflicts will be resolved using legal rules.

Second, it was the previous constitutional development. Authors of the Constitution built particularly upon the 1920 Constitutional Charter, but the subsequent constitutions also had some influence. Some forms of responsibility of the President were adopted from the previous constitutions, others were expressly rejected, and in some respects individual solutions overlapped.

And finally, constitution-makers were influenced by the basic idea that the legal framework of the Head of State's (non-)responsibility should at the same time serve as an expression of respect to the state itself, the office of the President and the person holding the office. ${ }^{15}$

As a result of the above-mentioned facts, the selected solution was to provide the President with strong protection against responsibility for their actions, ${ }^{16}$ the selected concept built upon the development of the past 75 years and distinguished among different forms of responsibility additionally the set rules were not of a proclamation nature.

\section{Constitutional responsibility}

In respect of the constitutional responsibility of the President, the draft Constitution itself underwent some development. According to the original draft of the government, ${ }^{17}$ the President was to only be responsible for high treason. Responsibility for this tort was to be established in criminal proceedings, where the Chamber of Deputies was authorised to file impeachment charges and the proceedings were to be held before the Constitutional Court. The only sanction was to be the loss of office, or the eligibility to be re-elected into office as the case may be.

As evidenced above, the proposers of the Constitution originally adopted the concept and formulation from the 1920 Constitutional Charter. The proceedings were to have a criminal nature, privilegium fori was to be maintained but the sanction, in contrast to the first-republic model, was to be of a purely constitutional nature. In the case of the sanction, we can see the influence of the constitutional development of the 1948-1992 period.

The proposed concept was rather complicated, as can be determined from the explanatory memorandum. ${ }^{18}$ High treason was approached as a tort of criminal law but not

15 See Filip 28. Similarly the Constitutional Court of the Czech and Slovak Federative Republic published under resolution No. 7/1992 Coll. of Judgments and Resolutions: "In view of the fact that our system of law does not give a clear answer to what all contents of the President's office description are, it is necessary in cases of doubt to interpret the President's actions so that they are made by the President in the position of the Head of State. The public objectively sees the President as the Head of State and the President alone has a greater political as well as moral responsibility and in view of that fact must be provided with greater protection."

16 In connection with the very generously approached protection of the President of the Republic against criminal responsibility, Professor Filip says that it allows the President to freely do anything, if necessary, to save the state, its unity and democratic foundations without having to consider whether they can, figuratively speaking, "enter the crossroads against a red light" - ibid 32.

17 Print of the Czech National Council No. 152 in the seventh term of office. Available online: http://www.psp.cz/eknih/1992cnr/tisky/t0152_01.htm [cit. 05/02/2015].

18 It stated that: "[The President] [m]ay only be prosecuted for high treason, the body of which is not defined by the Criminal Code as it particularly concerns political decisions. Otherwise, it would 
contained in the Criminal Code, tried according to the criminal procedure but on the basis of impeachment by a special body and before a special tribunal, where the result of the proceedings could be the imposition of a sanction other than of criminal nature. The fact that the draft of the Constitution failed to define the body of high treason did not contribute to its clarity either. For those reasons, the whole concept was changed when the draft was discussed in the Czech National Council.

The change was made by filing a comprehensive proposed amendment ${ }^{19}$ stipulating that the President could be prosecuted before the Constitutional Court on the basis of impeachment charges of the Senate for high treason. The only sanction could be the loss of the presidential office and the eligibility to regain it.

This proposal, eventually approved as a part of the Constitution of the CR, completed the previous constitutional development and introduced the institution of constitutional responsibility of the President into the Czech constitutional system.

A relatively serious defect of the Constitution, which was not removed until the amendment of the Constitution introducing direct election of the President, was the missing definition of the body of high treason. As pointed out by Professor Filip in his article ${ }^{20}$ the rule of law requires the bodies of crimes to be clearly defined.

It should be noted that the bodies should be defined at the level where the position of the organ itself is determined, as the definition of its responsibility is one of its basic determining factors. In the case of the President, it is, in addition, a part of the relationship to other constitutional organs and thereby a part of the system of separation of powers. These are purely constitutional matters and they should not be subject to redefinition by ordinary laws.

Eventually, the body of high treason was included in $\S 96$ of Act No. 182/1993 Coll., on the Constitutional Court. High treason meant actions of the President aimed against the sovereignty and integrity of the republic as well as against its democratic order.

Actions directed against selected constitutional values were identified as high treason establishing the constitutional responsibility of the President. Those values are particularly important characteristics of the existence of an independent state on the territory corresponding to the approved Constitution of the state, and of its political regime. ${ }^{21}$ The question of what degree of danger, or what intensity the possible high-treason actions of the President must have shall be first assessed by the submitter of the impeachment charges, and definitively by the Constitutional Court. It may be especially unclear when assessing what action of the President constitutes a threat to the democratic order of the republic. ${ }^{22}$

be necessary to not only apply only the Criminal Code, but also the Code of Criminal Procedure. Such proceeding would have to be conducted before court and the Chamber of Deputies could not be authorised to file impeachment charges. Loss of the presidential office as a punishment is not contained in the Criminal Code either."

19 Print of the Czech National Council No. 154 in the seventh term of office. Available online: http://www.psp.cz/eknih/1992cnr/tisky/t0154_01.htm [cit. 05/02/2015].

20 Filip 30.

21 For a detailed explanation of these values, see ibid 30.

22 It became apparent in the case of the amnesty of the President of the Republic proclaimed on 1 January 2013 and the subsequent dismissal of impeachment charges for high treason, which stated the proclamation of the amnesty in the given form as one of the reasons of accomplishment of elements of a constitutional tort. Although on 10 September 2009, in its resolution file No. III. ÚS $431 / 09$, the Constitutional Court held that "[un]punishment of perpetrators of serious property, 
The construction of the constitutional tort of high treason contained other weaknesses. First, constitutional values included in the body of high treason can also be infringed by actions for which the responsibility is assumed by another constitutional organ. In other words, a question is raised as to whether the President can commit high treason in exercising the powers under Article 63 of the Constitution, or those under Article 62 of the Constitution, which require cooperation of another constitutional organ.

Evaluation of such a case is complicated. Responsibility for an act of the President passes to the organ which participates in the exercise of their power. Nevertheless, it is necessary to emphasise that such an organ (e.g. the government in exercising the powers under Article 63 of the Constitution) only assumes the constitutional political responsibility. Not the constitutional one.

It is therefore conceivable that a situation might arise in which the President and the government commonly infringe one of the constitutionally protected values and the President bears the constitutional responsibility and the government bears the constitutional political responsibility, and its members possibly additionally bear the criminal responsibility. ${ }^{23}$ At the time of validity of the 1920 Constitutional Charter, a similar conclusion was reached by Dr. Emil Sobota. ${ }^{24}$ This conclusion also corresponds to the theoretical construction according to which shared powers are exercised by a single organ comprising of two, as also mentioned by Professor Weyr. ${ }^{25}$

As evidenced above, the construction of responsibility for acts of the President thoroughly combines constitutional, constitutional political and criminal responsibility. There may be situations where an action of one official will lead to a different type of responsibility as compared to that of the identical action of an official acting jointly with the first.

Another complicated situation emerges where the selected presidential powers are delegated under Article 66 of the Constitution because the President is unable to perform their duties, or the office of the President is vacated.

In this case, constitutional responsibility for the exercise of those powers does not pass to the constitutional officials. Where their exercise of delegated powers infringes any of the constitutionally protected values, which would mean, in the case of the President, acts of elements which would amount to high treason, they will bear no more than the constitutional political responsibility and criminal responsibility.

This conclusion is based on the fact that the constitutional responsibility of the President has been established because the President is not politically responsible for the performance of their duties and cannot be criminally punished for the performance. This is not the case for the serving constitutional officials. As they can bear constitutional political responsibility as well as criminal responsibility there is no reason why they should be

financial and economic criminality with reference to unconstitutional delays in criminal proceedings might lead to a general weakening of citizens' confidence in democratic rule of law", it did not take this argument into account in the proceedings on the impeachment charges for high treason, resolution file No. Pl. ÚS 17/13.

${ }^{23}$ Constitutional political responsibility of the President is excluded by Article 54(3) of the Constitution; their criminal responsibility was excluded by the original wording of Article 65(1) of the Constitution. On the contrary, the constitutional responsibility of the government has not been established at all.

24 Emil Sobota et al., Československý president republiky. Státoprávní instituce a její život (Prague 1934) 98.

${ }^{25}$ Frantisek Weyr, Ústavní právo Československé (Prague 1937) 191. 
punished alternatively, as the enforcement of constitutional responsibility is an alternative punishment. ${ }^{26}$

Another open question at the time of adoption of the Constitution was whether constitutional responsibility was tied to the person holding the office of the President or whether it was connected strictly with the performance of duties of the President. In other words, can a former President be tried for high treason after termination of their office.

The very construction of constitutional responsibility of the President leads to the conclusion that the responsibility can be enforced even after termination of the office. Is the tort of high treason anything else but an alternative tool of enforcement of responsibility for the grossest infringement of constitutionally protected values against a President who bears no constitutional political and criminal responsibility? As stated by Professor Filip, high treason has changed from an original tool of protection of a sovereign into a tool of protection of the state against the actions of its head. ${ }^{27}$ For this reason, it is correct to try unconstitutional actions of a former President. The fact that reasons for possible impeachment charges were discovered only after termination of their term of office should not be an obstacle. On the contrary, in some cases, it cannot be otherwise.

This consideration is supported by impending sanctions. It is not only the loss of office, but also the loss of the eligibility to be re-elected to office. As it is the only sanction threatening the President, who bears no other responsibility, it is not possible to renounce it. Not to mention that the termination of presidential office should certainly not be an obstacle to initiation of proceedings before the Constitutional Court, which is the only way of assessing the actions of the former President that might seem, for documented reasons, to grossly infringe fundamental constitutional values.

Nevertheless, in its judgment Pl. ÚS 17/13, ${ }^{28}$ pronounced on 27 March 2013, the Constitutional Court took an opposite stance in this respect. It supported the conclusion that if in doubt, it was necessary to give preference to the more favourable interpretation for the defendant. Therefore, it refused to try the impeachment charges. The Constitutional Court thereby actually restricted the already narrowly defined constitutional responsibility of the President. Another thing is that the said judgment has practically no significance for the future, as will be shown hereafter.

\section{Constitutional political responsibility}

Constitutional political responsibility is a tool of control over an appointed or elected organ or official by the one who appointed or elected them into office. Responsibility is not only established for possible violation of legal regulations, even though it is not impossible, but particularly for the loss of confidence in the exercise of the duties inherent in the office. The reason for the establishment of constitutional political responsibility is primarily the loss of political confidence in the actions of the respective official or organ. ${ }^{29}$ Hence, it is the responsibility established by legal regulations, but also having an inherently political nature.

26 Similarly Filip 29.

27 ibid 29.

28 Available online in English: http://www.usoud.cz/en/decisions/?tx_ttnews[tt_news] $=2345 \& \mathrm{c}$ Hash=a6e71152c31c6aea5845bd9d4fe5218e [cit. 05/02/2015].

${ }_{29}$ As Professor Filip states, this loss of confidence is not ascertained by means of investigation and providing evidence, but by political discussion and a subsequent vote on (no-)confidence (Filip 27) 
A typical example of constitutional political responsibility in parliamentary systems is the responsibility of the government to the Parliament or one of its chambers. This is the solution also adopted by the Constitution of the CR. Concerning the position of the President, the authors of the Constitution diverged from this variant. The authors of the Constitution did not use the mechanism introduced by the 1960 Constitution, according to which the President had been responsible to the National Assembly, or Federal Assembly. Rather it was interpreted, as the case may be, and, as deduced by theory, responsibility had been probably enforced by removal of the President by the Parliament. ${ }^{30}$ On the contrary, the authors of the Constitution accepted the concept of the 1920 Constitutional Charter. For one thing, they stipulated in Article 54(3) of the Constitution that the President was not responsible for the performance of their duties, and further they did not embody any mechanism for removal of the President for constitutional political reasons. Nevertheless, they did not completely guarantee the transfer of this type of responsibility to another organ.

Thereby, this provision may come into conflict with one of the fundamental principles on which the Constitution of the $\mathrm{CR}$ is built, i.e. the principles of republicanism. It determines the type of government system and, hence, it is superior to any possible rules determining the form of government within the system of government, or even modification of the form of government.

There are two fundamental rules in a republic. According to the first, every citizen may run for public office. At the same time, according to the second rule, every public official is responsible for the performance of their duties in contrast to monarchies. Therefore, a situation where the Head of State would be equipped with powers, yet bear no responsibility for exercising them, would be in conflict with the principles of a republic. ${ }^{31}$

This problem can only be resolved by systematic interpretation, or more precisely, when we talk about the creation of a constitutional text, then incorporation of such tools that enable the transfer of constitutional political responsibility from the President, who is not supposed to be burdened by it, to another organ.

Although in 1992 constitution-makers were repeatedly referring to the model of the 1920 Constitutional Charter, they did not strictly use its concept as a base. While the constitutional regulation of the First Czechoslovak Republic expected full countersignature, as every "act of the governmental and executive powers" had to be countersigned, the Constitution of the CR is only based on partial countersignature and introduces a number of powers of the President not shared with the government. The result is a hybrid model combining two previous arrangements. ${ }^{32}$

In reality the President gained an even more independent position in relation to the government. This position of the President was thanks to the provision of Article 63(3) of the Constitution. Pursuant to this provision, only the exercise of power in the form of decisions is subject to countersignature.

${ }^{30}$ For details, see footnote 13.

${ }^{31}$ For details see e.g. Jan Kudrna 'The Question of Conducting Direct Elections of the President in the Czech Republic (A Live Issue for 20 Years Already)' (2011) 18/4 Jurisprudencija (Jurisprudence) 1299. Available online: https://www3.mruni.eu/ojs/jurisprudence/article/download/1682/1592 [cit. 05/02/2015].

32 For details see e.g. Jan Kudrna 'Záplatování jako nevyhnutelná základní metoda př́stupu k Ústavě ČR' in Gerloch A. Kysela et al. (eds), 20 let Ústavy České republiky: ohlédnutí zpět a pohled vpřed (Vydavatelství a nakladatelství Aleš Čeněk 2013) 84-101. 
Relatively soon after the adoption of the Constitution of the CR, the Constitutional Court had to address this issue. In its judgment file No. Pl. ÚS $43 / 93,{ }^{33}$ the Constitutional Court particularly explained what the term "decision" meant. According to the Constitutional Court, "it is such exercise of power which changes or confirms a legal situation (even those of individual persons)". The Constitutional Court emphasised that the "[d]ecision rendered cannot be, therefore, understood as any 'decision to' act in a certain way."

Thereby, the Constitutional Court confirmed that the government's ability to influence the way the President acts was even narrower than it might have seemed at first glance. For example, in regard to powers related to foreign policy of the state as defined in Article 63(1) (a) and (b), there is a relatively large space for the independent activities of the President, which are not subject to the Prime Minister's countersignature.

A significant lack of equilibrium may arise in this area between the viewpoints of the President and those of the government.

The imbalance can only be overcome by systematic interpretation. The President cannot be deprived of those powers and their contents cannot be denied as the text of the Constitution is clear in this respect. Alternatively, the government cannot be denied the option to exercise the countersignature as a tool of expressing its political viewpoint. ${ }^{34}$

Harmony can only be achieved if the President preliminarily discusses their planned political steps in representation of the state and negotiation of international treaties with the government so that both parties can avoid a collision for which the Czech Republic would pay a high political external price. This means exercising powers of the President as well as the government in mutual accord and on the basis of mutual self-restrictions. ${ }^{35}$

The principle of self-restriction and cooperation, even though in various degrees of intensity, can be applied to decision-making under all countersigned powers of the President. After all, it already follows from the above-described construction by Professor Weyr, according to which shared powers are exercised by a single new organ comprising of two. ${ }^{36}$ Where there are two organs required to exercise a power, they must find agreement. It will often take the form of a compromise, where the organ assuming overall responsibility for the decision certainly has the right to exercise its influence.

It is possible from the formal constitutional point of view that the government fails to exercise the political aspect of countersignature and makes use only of its legal aspect. This may, however, result in a situation where the government would abandon its constitutional political control role in relation to the President, giving considerable independence to the President and, at the same time, it would bear full constitutional political responsibility.

33 Published under No. 91/1994 Coll.

34 In this context it should be noted that the legal opinion of the government expressed by the Prime Minister, Minister of Justice and Chairman of the Government Legislative Council on 9 January 2013, and repeatedly over the subsequent days, that the countersignature does not have a political but only a legal content is unfounded, particularly with regard to the constitutional development of the institute of countersignature. It would result in a situation where the President of the Republic would be completely free in their actions without bearing constitutional political responsibility for said acts. The institute of countersignature is a tool for ensuring the alternative enforcement of constitutional political responsibility of an official who does not bear responsibility in this respect.

35 For details see e.g. Kudrna 'The Question of Conducting Direct Elections of the President in the Czech Republic' 1299-1300. Available online: https://www3.mruni.eu/ojs/jurisprudence/article/ download/1682/1592 [cit. 05/02/2015].

36 See footnote 24 . 
In respect to the constitutional political (non-)responsibility of the President, the situation is further complicated by the fact that within the Czech Republic the countersignature is effected by the Prime Minister or a member of the government authorised by them. Consequently, the control over exercise of presidential powers primarily lies in the hands of the Prime Minister, not the government as such. This can also be considered a weakening of the government's control function, particularly compared to the pre-war situation. The countersignature was then carried out by the responsible member of the government under $\S 68$ of the 1920 Constitutional Charter. The position of a minister in relation to the government is weaker than that of the Prime Minister. Although not impossible, it is easier for the government to bind its individual members than the Prime Minister, especially when they are equipped with the power to propose removal of members of their government.

The constitutional regulation directly embodies a situation where the Prime Minister countersigns, but the responsibility is borne by the whole government, although the government does not in fact need to be informed in advance about the subject of responsibility that it will assume. ${ }^{37}$ Ideally, the Prime Minister can inform their government and act according to its resolution. Such a procedure would also be more appropriate as members of the government would not be confronted with a fait accompli. Nevertheless, the Prime Minister is not obliged to follow this procedure. Consequently, a situation may occur where members of the government can only express their possible disagreement with countersignature ex post, in an extreme case in the form of resignation.

In conclusion, the authors of the Constitution of the CR fully absolved the President from constitutional political responsibility and, in addition, they strengthened this organ by releasing many of their powers from the control of other constitutional organs. This damaged, to a considerable extent, the concept of the parliamentary organisation in which the President was institutionally limited.

\section{Criminal responsibility}

The authors of the Constitution of the CR drafted the criminal responsibility of the President very generously. In fact, they completely ruled out any criminal prosecution of the President, whether within judicial or administrative punishment. Within Article 65 the Constitution distinguishes between two categories of torts according to the criterions of their type and from the moment that they are committed.

First, the Constitution ruled out the possibility to detain and prosecute the President during the term of their office. This immunity covered all crimes, offences or other administrative torts. Given the formulation of the Constitution, it is an obstacle to prosecution for all mentioned types of torts which the President would commit before assuming the office or, where offences and torts are concerned, also during the term of their office.

In regard to crimes possibly committed by the President during the term of their office, the Constitution laid down special regulations embodying a very wide substantive immunity. Within the provision of Article 65(3), prosecution of the President for those crimes was wholly excluded.

In this way, the President was made immune from prosecution for the term of their office and their criminal responsibility for torts committed during the term of their office

37 As was allegedly the case of the amnesty of 1 January 2013. 
was expressly ruled out. It should be pointed out that the Constitution ruled out criminal responsibility of the President in relation to all crimes, not only those of an "official" nature. The criterion was the time of their committing, not their nature.

Criminal non-liability applied only to the President, not constitutional officials acting on their behalf if required. In addition, no one assumed criminal responsibility for the President with regard to the individual approach to culpability in modern criminal law.

Responsibility for acts of the President of the Czech Republic from 8 March 2013

Although when discussing the direct election of the President it was often heard that it should only occur for a change of the Head of State, but everything else was to remain unchanged, ultimately the result was different. The amendment of the Constitution carried out by Constitutional Act No. 71/2012 Coll. had greater implications. The amendment rather considerably changed inter alia the constitutional regulation of responsibility for acts of the President. While the constitutional political responsibility remained unchanged, the constitutional and criminal responsibility was subject to quite considerable changes.

\section{Constitutional responsibility}

The framework defining constitutional responsibility of the President underwent the most noticeable changes in connection with the introduction of the direct election of the Head of State.

First, the last reminiscences of high treason, originally an institute of criminal law, as adopted by the constitutional regulation of the inter-war Czechoslovak Republic from Austrian criminal law, were removed. The loss of the presidential office and the eligibility to be re-elected to office is no longer considered a "punishment" in Article 65(2) of the Constitution. In the explanatory memorandum, ${ }^{38}$ the proposer directly draws attention to the difference between criminal and constitutional sanctions and justifies the change of formulation of the above-mentioned provision as an effort to avoid problems with interpretation.

This change can only be appreciated when differentiating amongst the different forms of responsibility that may be considered in the case of the President, and which, as repeatedly shown above, often overlapped in the previous regulations.

Another fundamental and predominantly positive change is the definition of the constitutional tort of high treason in the Constitution. The previous situation where only the law defined what is meant by a term embodied in the Constitution, but was still crucial for the definition of the position of the President, was extremely undesirable. Elements of the body of high treason remained unchanged.

Nevertheless, the constitutional responsibility of the President was strengthened as in addition to high treason, the President also bore constitutional responsibility for "gross violation of the Constitution or another part of the constitutional order". The Constitution of the $\mathrm{CR}$ ranked among the many constitutions that are protected against violation by the Head of State. This change is positive.

38 Parliamentary print No. 415 in the sixth term of office. Available online: http://www.psp.cz/ sqw/text/tiskt.sqw? $=6 \& \mathrm{CT}=415 \& \mathrm{CT} 1=0$ [cit. 05/02/2015]. 
However, it raises a fundamental question. The question is whether it is suitable to distinguish among violations of constitutional regulations by intensity. Is it acceptable for the sanction to only apply to "gross" violations of constitutionality and not to "light" deduced a contrario - ones? This regulation probably reflects the effort to protect the President against prosecution for petty or controversial issues. Hence, the constitutionmakers keep approaching the Head of State with a higher level of respect, which they wish to maintain. ${ }^{39}$ Yet distinguishing of this type is not appropriate. It implies that some violations of constitutionality are not torts and, therefore, they are in fact acceptable.

The most significant change which, to a considerable extent, made provisions on the constitutional responsibility of the President almost obsolete, affected the procedure of filing a constitutional action. The existing regulation was significantly toughened. Recently, approval of both chambers by constitutional majority is required and, in addition, approval of the Chamber of Deputies must be granted within three months from the date when the Senate asks for it. If the Chamber of Deputies fails to do so, the approval is considered not granted.

In the explanatory memorandum, the proposer states that the aim of this enforcement is to create "an adequate safeguard against unjustified proposals which would, in the end, damage the whole of the Czech Republic, and to emphasise the extraordinariness of the institute of impeachment".

This argument is relevant to a certain extent, but it is not crucial. The main argument for toughening the procedure, which the proposer, however, does not mention, should be the effort to protect the directly elected President against potential calculated attempts of the Parliament, or one of its chambers, to remove them.

Unjustified proposals which might damage the Czech Republic certainly cannot be excluded, but as shown by the example of the proceedings of high treason up until the beginning of 2013 , even within the rather turbulent social atmosphere, it was not easy to gain the required support in the Senate, which was definitely not favourable to the then President. In any case, one can agree with the proposer that the procedure was in need of reform in order to make the submission of unjustified proposals more difficult, but the reasons given for this change should have been different.

Nevertheless, one cannot agree with making the proposal conditional upon the support of constitutional majorities in both chambers of the Parliament, moreover intensified by a lapse period. The set rules are strict to such extent that except for the most flagrant cases of high treason, they virtually exclude the possibility to prosecute the President. In the end, the procedural rules effectively form an obstacle to prosecution and thereby make the constitutional responsibility of the President an almost academic matter. It would be sufficient to lay down a condition of approval for filing the action by three fifths of the present senators.

One procedural specification was made at the level of laws, as a provision was added to $\S 98(3)$ of the Act on the Constitutional Court stipulating that prosecution of the President was not influenced by the fact that their office had terminated by expiration of their term of office. Once this provision took effect, resolution of the Constitutional Court file No. P1. ÚS

39 The question is why this should be the case. Undisturbed operation of other organs is more important for regular functioning of the state but no respect of that sort is shown to those organs. Moreover, while it is typical for monarchies built on exclusiveness that they are reinforced by trust and respect, quite the opposite is true in republics. Republics are strengthened by an equal approach; privileges, on the contrary, cause their delegitimisation and erosion. 
$17 / 13$ became irrelevant for the future. This change, however, has no influence on the fact that prosecution can be initiated only against an acting President. This conclusion follows from the wording of the Constitution and the Act on the Constitutional Court.

\section{Criminal responsibility}

As of 8 March 2013 the rules relating not only to the field of criminal responsibility for acts of the President and the existing approach to this type of responsibility of the Head of State underwent drastic reforms resulting in near revolutionary reactions.

The change was caused by the complete deletion of the regulation contained in the original Article 65(3) of the Constitution. It had established absolute substantive immunity in the case of any crime committed by the President during their term of office. Thereby, Professor Filip's consideration that the President is granted wide protection in the circumstance where it would be necessary for them to violate the legal order in the interest of saving the state and its system of government, ceased to be justified. ${ }^{40}$ Criminal prosecution of the directly elected President for torts committed during the term of their office is possible. ${ }^{41}$

In the field of criminal responsibility, only the procedural immunity of the President established by Article 65(1) of the Constitution was maintained. Not even after 8 March 2013 can the President be detained or prosecuted for a crime, offence or other administrative tort. This procedural obstacle to prosecution only lasts for the term of office of the President. It means that after termination of their office the obstacle to criminal prosecution ceases to exist and the former President can be prosecuted in the standard way.

It is worth remembering that as long as the immunity as a statutory obstacle lasts within the meaning of $\S 10(1)$ and $\S 11(1)(c)$ of the Code of Criminal Procedure, ${ }^{42}$ limitation periods are interrupted under $\S 34(3)(a)$ of the Criminal Code. ${ }^{43}$ As concerns criminal prosecution, termination of the office of the President means that all obstacles cease to exist and full equality before the law is re-established.

The situation is more complicated in the case of offences. $\S 20(1)$ of the Act on Offences $^{44}$ would be applicable, stipulating that no offence can be heard after expiration of one year from it being committed. With this type of tort, it would, in principle, depend on how long before the termination of their office the President committed the offence. ${ }^{45}$

40 See Filip 32.

${ }^{41}$ A specific breakthrough in this respect occurred as early as on 1 October 2009 when the Rome Statute of the International Criminal Court became binding on the Czech Republic. In its Article 27, it prohibits taking any official capacity into consideration when evaluating criminal responsibility for acts to be tried by the Court under the Statute, and in the provision of paragraph 2, it expressly stipulates that no immunities under national law will be taken into account.

42 Act No. 141/1961 Coll., on Criminal Judicial Proceedings, as amended.

43 Act No. 40/2009 Coll., the Criminal Code, as amended.

44 Act No. 200/1990 Coll., on Offences, as amended.

45 In this respect, I disagree with the opinion of Professor Filip who refers to Section 9 of the Act on Offenses and deduces that hearing a potential offence committed by the President is absolutely excluded. See Filip 36. I hold the opinion that Article 65(1) of the Constitution provides protection against prosecution to the President, but not a former one. At the same time, this provision is the "law" to which the aforementioned Section 9(1) of the Act on Offences refers. However, it provides procedural protection, not a substantive one, and therefore it is impossible to rule out a situation where the obstacle to hearing an offence ceases to exist. 
The Constitution generally puts obstacles upon hearing of other administrative torts during the term of the presidential office. However, the Constitution does not equip the former President with any protection against hearing of the torts after termination of their office.

The effects of the change in the field of the criminal responsibility for the actions of the President constitute a shift from one extreme to another. While the President was previously equipped with an unusually extensive criminal immunity for any acts committed during the term of their office, the new regulation adopted the opposite solution. The President is only protected during the term of their office and once it terminates, they are no longer protected at all.

I believe that the current solution is not an appropriate one. In terms of criminal responsibility at least, any kind of immunity from prosecution for statements of the President should be maintained. In addition, in my opinion it would be worth considering distinguishing between torts committed by the President in the performance of their duties and other torts. Whereas, in relation to other torts there is no reason why the President could not be prosecuted after termination of their office, in the case of the "official" torts I am of the opinion that they should at least be partially subject to the constitutional responsibility and not the criminal element. After all, a large part of them will accomplish the elements of gross violation of constitutional regulations.

\section{CONCLUSION}

The issue of responsibility for acts of the President is not a simple one. Its complexity is caused by the special position of an individual Head of State from whom, despite the fundamental principles of the republic, something more is expected than the mere fulfilment of specific official duties. Within Czech society these expectations are traditionally even greater. ${ }^{46}$ From one angle these expectations are evident in the fact that the office of the President was maintained without interruption, even during the period of the democratic people's regime, while all similar states preferred, at least for some time, collective bodies as leaders of the countries' constitutional systems. Another aspect is that these considerable and even excessive expectations manifested themselves in the rather controversial embodying of the position of the President in the currently valid Constitution. According to one perspective the authors of the Constitution declared their effort to establish a parliamentary form of government, but conversely, they "freed" the President from the influence of other constitutional organs in an unusual form. This internal ambiguity also became evident in the concept of (non-)responsibility for acts of the President.

A failure to clarify differences among various forms of responsibility, which might be considered by constitutional law in the case of supreme officials, played its part as well. Individual institutes overlap in many respects, which certainly does not contribute to the clarity and comprehensibility of the whole system of responsibility.

The last amendment of the Constitution meant a rather significant shift in the described field that will influence the overall position of the President. The fact that from the substantive point of view the constitutional responsibility of the President was extended, and in the field of criminal law the President was entirely deprived of substantive immunity,

46 See the above-mentioned resolution of the Constitutional Court of the Czech and Slovak Federative Republic No. 7/1992 Coll. of Judgments and Resolutions. 
will certainly have some effect. The President has become responsible to a greater extent, which means at least a partial removal of the basic conflict described at the beginning of this text. It is the conflict between the principle of republicanism, the immanent part of which is the necessity to account for the performance of duties connected with the assigned office on the basis of the principle of equality, and the principle of non-responsibility of the President of the Czech Republic, or the limited responsibility as the case may be.

This conflict could only be resolved by the requirement for constraint and selfrestriction of the President in the performance of their duties in order to avoid a situation where they should be responsible for their political actions, but the responsibility would be excluded. The more the President, or any other constitutional official, is directly responsible for their actions, the freer their actions can be.

In the case of the President, this means that they can be more active in comparison to the situation before 7 March 2013, and to the extent to which their responsibility was strengthened. This, however, weakens their role as a "representative of the state, guarantor of the order and moderator of political disputes," which is "not intended for the realisation of their own policy". ${ }^{47}$ Independence and freedom are always connected with responsibility. At present, the responsibility of the President of the Czech Republic is greater than before.

Although the approach to responsibility of the President shifted in a desirable direction, the shift also includes many critical points. The extension of the constitutional responsibility of the President and strengthening of their criminal responsibility can be assessed as positive. On the contrary, the critical flaw is the setting of procedural rules which will more likely make the enforcement of constitutional responsibility impossible rather than possible. A considerable weakness is the approach to criminal responsibility, where the constitutionmakers should have unambiguously distinguished the different types of crimes that might be committed by the Head of State during the term of their office. The opportunity to address critical loopholes in the field of constitutional political responsibility for acts of the President was completely missed.

On the whole, it can be stated that the current regulation of responsibility for the actions of the President has many weak points. This may be caused by the fact that the issue was not primarily addressed as a constitutional problem.

\section{LITERATURE}

Bahýlová, L. et al., Ústava České republiky. Komentár [The Constitution of the Czech Republic. Commentary] (Linde 2010) 793-825.

Filip, J., 'K ústavní odpovědnosti v ČR a odpovědnosti hlavy státu zejména za velezradu' [On the constitutional responsibility in the Czeh Republic and on the responsibility of the head of state, especially for high treason] (2010) 1 Časopis pro právní vědu a praxi 21-39.

Kudrna, J., 'The Question of Conducting Direct Elections of the President in the Czech Republic (A Live Issue for 20 Years Already)' (2011) 18/4 Jurisprudencija (Jurisprudence) 1295-1321.

Kudrna, J., 'Záplatování jako nevyhnutelná základní metoda př́stupu k Ústavě ČR' [An inevitable basic attitude to the amending of the Constitution in the Czech Republic] in Gerloch A. Kysela et al. (eds), 20 let Ústavy České republiky: ohlédnutí zpět a pohled vpřed [20 years of the Constitution

${ }^{47}$ As stated e.g. by Jan Wintr. 'Prezident republiky jako reprezentant státu, garant řádu a moderátor politických sporů’ in V. Šimíček (ed.), Postavení prezidenta v ústavním systému České republiky (Brno 2008) 25. 
of the Czech Republic: Looking back and looking ahead] (Vydavatelství a nakladatelství Aleš Čeněk 2013) 84-101.

Sobota, E. et al., Československý president republiky. Státoprávní instituce a její život [The Czechoslovak President. The state institution and its life] (Prague 1934).

Weyr, F., Ústavní právo Československé [The Czecho-slovak constitutional law] (Prague 1937).

Wintr, J. 'Prezident republiky jako reprezentant státu, garant řádu a moderátor politických sporů' [The President of Republic as a representative of the state, guarantee of order, and moderator of the political disputes] in Šimíček, V. (ed.), Postavení prezidenta v ústavním systému České republiky [The position of president in the contitutional system of the Czech Republic] (Brno 2008) 24-34. Zdobinský, S. et al., Československé státni právo [The Czecho-slovak State law] (Prague 1988). Ziomecki, M., 'Obciach i szacun' [Embarrassment and respect] (2013) 18 Przekrój (3536) 15. 